\begin{tabular}{|l|l|l||}
\hline \multicolumn{2}{|c|}{ PublisherInfo } \\
\hline \hline PublisherName & $:$ & BioMed Central \\
\hline \hline PublisherLocation & $:$ & London \\
\hline \hline PublisherImprintName & $:$ & BioMed Central \\
\hline \hline
\end{tabular}

\title{
Influenza A infection interferes with the development of asthma
}

\begin{tabular}{|l|l|l||}
\hline \multicolumn{2}{|c|}{ ArticleInfo } \\
\hline \hline ArticleID & $:$ & 1640 \\
\hline \hline ArticleDOI & $:$ & $10.1186 /$ rr-2001-68572 \\
\hline \hline ArticleCitationID & $:$ & 68572 \\
\hline \hline ArticleSequenceNumber & $:$ & 51 \\
\hline \hline ArticleCategory & $:$ & Paper Report \\
\hline \hline ArticleFirstPage & $:$ & 1 \\
\hline \hline ArticleLastPage & $:$ & 1 \\
\hline \hline & & RegistrationDate $: 2001-9-19$ \\
& $:$ & Received 2000-9-29 \\
\hline ArticleHistory & $:$ & Accepted 2001-9-19 \\
& $:$ & OnlineDate \\
\hline \hline ArticleCopyright & $:$ & Biomed Central Ltd2001-9-19 \\
\hline \hline ArticleGrants & $:$ & \\
\hline \hline ArticleContext & $:$ & 129312211 \\
\hline \hline
\end{tabular}


Andrea Heinzmann, Aff1

Corresponding Affiliation: Aff1

Aff1 Wellcome Trust Centre for Human Genetics, Oxford, UK

\section{Keywords}

Allergen sensitization, asthma, bronchial hyper-reactivity, influenza A virus infection, mouse model

\section{Context}

The effects of viral infections of the respiratory tract on the development of respiratory allergen sensitization and asthma are discussed. Several epidemiological studies provide evidence that viral infections in early childhood protect against the development of asthma and allergies, however, other studies have shown that viral infections enhance the risk of asthma development in children. In a murine model of asthma, inhalation of antigen induces CD4 T cell tolerance and prevents airway hyperreactivity (AHR) and the production of antigen-specific IgE. This study used the same murine model to investigate the effects of influenza A virus infection on the induction of antigen tolerance to ovalbumin (OVA) and the development of AHR.

\section{Significant findings}

Mice exposed to OVA intranasally three days after infection with influenza A virus showed an increased production of interleukin (IL)-4, IL-5, IL-13, IFN-? and OVA-specific IgE and subsequently developed AHR. Neutralization of both IL-4 and IL-5 did not abrogate the induction of AHR, but greatly reduced lung eosinophilia. In contrast, respiratory exposure to OVA 15-30 days after infection abrogated the induction of an allergen-specific tolerance but led to a Th1-biased immune response with little or no production of IL-4, IL-5 and IL-13. Moreover it protected from the development of AHR. This protection was abrogated by neutralizing IFN-?. The authors suggest that the time interval between viral infection and respiratory allergen exposure is crucial in determining whether viral infection will enhance, or protect against, the development of respiratory allergen sensitization and asthma. 


\section{Comments}

Several earlier studies used murine models of asthma to investigate the effect of influenza A infection on allergen sensitization and AHR. However, this is the first to report on the relationship between the phase of influenza A viral infection and antigen exposure on the development of AHR. The results suggest that early exposure to respiratory allergen during viral infection biases towards a Th2-permissive immune response, with the development of significant AHR and eosinophilia. In contrast, exposure in late stages of infection leads to a Th1-predominant response and decreased airway reactivity. This might at least partially explain the conflicting findings of earlier studies cited above; however, it should be noted that the study has been performed in a rodent model and still needs confirmation in humans. Furthermore, it might prove useful in future studies to investigate the composition of inflammatory cells in the bronchial mucosa at different stages of viral infection and their potential influence on the sensitization outcome.

\section{Methods}

$\mathrm{BALB} / \mathrm{c}$ mice, whole body plethysmograph, broncoalveolar lavage and cell count, lung histology, in vitro proliferation assay, cytokine assay, ELISA

\section{Additional information}

\section{References}

1. Tsitoura DC, Kim S, Dabbagh K, Berry G, Lewis DB, Umetsu DT: Respiratory infection with influenza A virus interferes with the induction of tolerance to aeroallergens. J Immunol. 2000, 165: 3484-4391.

This PDF file was created after publication. 